\title{
Notes on Acer laurinum (Sapindaceae) in freshwater swamp forest in Singapore
}

\author{
P.J. Chan, Y.Y. Ting, N.E. Rahman, R. Chong, W.N. Lam \& K.Y. Chong \\ Department of Biological Sciences, National University of Singapore, \\ 16 Science Drive 4, Singapore 117558 \\ kwek@nus.edu.sg
}

\begin{abstract}
Acer laurinum Hassk. was recently recorded as both a new species and genus for Singapore from the Nee Soon swamp forest in the Central Catchment Nature Reserve, but little is known about its biology and ecology. Here, the species is described and notes on its distribution, ecology and proposed conservation status in Singapore are given.
\end{abstract}

Keywords. Conservation assessment, distribution, ecology, flora

\section{Introduction}

The Nee Soon catchment contains the last substantial intact tract of freshwater swamp forest in Singapore, referred to as the Nee Soon swamp forest (NSSF). There have been many recent new records and rediscoveries from this catchment, underpinning its high floristic value (see Chong et al., 2018). As part of fieldwork for a series of projects to understand the vegetation ecology of the NSSF, two individuals (a sapling and a mature tree) of Acer laurinum Hassk. were encountered. A specimen comprising a single leafy twig was collected from the sapling (Lam, Chan \& Ting SING2020659 [SING0294231]) on $4^{\text {th }}$ February 2020, but not from the other, mature individual, which had a diameter of $48.3 \mathrm{~cm}$ and a height of approximately $20 \mathrm{~m}$. Previously, Acer laurinum had only been recorded for Singapore in a checklist of the flora of the NSSF by Wong et al. (2013) based on a single collection from 2010 (Gwee SING2010-475 [SING0144684]). As the species is mainly found in subtropical evergreen forests (Xu et al., 2008) and tropical montane forests (Bloembergen, 1948 [who referred to it under the name Acer niveum Blume]; Noorsiha, 2004; van Welzen, 2017), its occurrence in NSSF in Singapore adds a valuable insight into an understanding of this species' biology.

Acer laurinum is not easily confused with other native species. Sapindaceae species native to Singapore all bear pinnately compound leaves, with Acer laurinum and Dodonaea viscosa Jacq. being the only two exceptions with simple leaves. The long $(>6 \mathrm{~cm})$, pulvinate petioles and oppositely-arranged, basally tri-veined, abaxially glaucous leaves of Acer laurinum are also a unique combination of traits that distinguish it from all other tree species in Singapore. For example, many Malvaceae species have long, pulvinate petioles and basally tri-veined leaves, but these leaves are always arranged spirally; many Melastomataceae species have oppositely-arranged, basally 
tri-veined leaves, but none of these have long pulvinate petioles; Maclurodendron porteri (Hook.f.) T.G.Hartley (Rutaceae) possesses oppositely-arranged leaves with pulvinate petioles, but its leaves are not basally tri-veined; and Neolitsea zeylanica (Nees \& T.Nees) Merr. (Lauraceae) has basally tri-veined, abaxially glaucous leaves but the petioles are not pulvinate.

The genus and species are described here for Singapore with a discussion on the distribution, ecology and proposed national conservation status of the species. As only two individuals that were neither flowering nor fruiting were observed, our description of seedlings, saplings, mature tree height, inflorescences, fruits and seeds are based on the more comprehensive accounts of Bloembergen (1948), Whitmore (1973), Noorsiha (2004) and Xu et al. (2008). Bloembergen (1948) used the name Acer niveum and Whitmore (1973) used the name Acer caesium (Reinw. ex Blume) Kosterm., nom. illeg., non Wall. ex Brandis; see details in Delendick (1980). Both of these names are synonyms of Acer laurinum.

Acer L. is a genus of shrubs and trees comprising approximately 130 species (Xu et al., 2008). Commonly known as maples, members of the genus are usually recognised by their characteristic palmately lobed leaves and double samaras. Samaras are laterally compressed, simple, dry indehiscent winged fruits that are dispersed by wind. In Acer spp., two samaras, each with a single seed, are connected on the seedcontaining ends to form a double samara. Commercially, the sap of Acer saccharum Marshall is valued for production of maple syrup and some Acer spp. are valued as ornamental and timber trees (Xu et al., 2008; Harris et al., 2017). Acer is primarily a temperate genus, mainly distributed across Europe, Asia, Africa, Central and North America, with the highest diversity centered in eastern Asia (Xu et al., 2008; LaFrankie, 2010). There are only a few species native to tropical regions. Acer is the type genus of the largely temperate family Aceraceae, which had been kept distinct from Sapindaceae despite morphological evidence of their similarity (Radlkofer, 1890, 1933) until Aceraceae was reduced to synonymy (APG, 2003; Harrington et al., 2005). Based on phylogenetic evidence, Acer is now included in subfamily Hippocastanoideae of the Sapindaceae (APG, 2003; Harrington et al., 2005).

\section{Notes on Acer in Singapore}

Acer L., Sp. Pl. 2: 1054 (1753); Koorders \& Valeton, Bijdr. Boomsoort. Java 9: 252 (1903); Bloembergen, Fl. Males. ser. 1, 4: 3 (1948); Whitmore, Tree Fl. Malaya 2: 1 (1973); Noorsiha, Tree Fl. Sabah Sarawak 1: 1 (2004); Xu et al., Fl. China 11: 516 (2008); van Welzen, Fl. Penins. Malaysia ser. 2, 6: 69 (2017). - TYPE: Acer pseudoplatanus $\mathrm{L}$.

Tree or shrubs. Buds with perules. Leaves simple, opposite-decussate, petiolate, mostly tri-veined at base, exstipulate. Inflorescence racemose, corymbose or paniculate. Flowers unisexual, staminate and pistillate flowers on same or different tree; calyx and corolla $4-5$; stamens $4-10$, usually 8 , hypogynous or perigynous, filaments free; 
ovary superior, 2-locular, laterally compressed, styles 2 , free or connate at base, ovules 2 in each locule. Fruit a double samara comprising of 2 one-winged samaras, usually one-seeded. Seed without endosperm, radicle elongate, cotyledons foliaceous, or thickened, plicate, involute or flat.

Acer laurinum Hassk., Tijdschr. Natuurl. Gesch. Physiol. 10: 138 (1843); Whitmore, Tree Fl. Malaya 2: 1 (1973); Noorsiha, Tree Fl. Sabah Sarawak 1: 3 (2004); Xu et al., Fl. China 11: 547 (2008); van Welzen, Fl. Penins. Malaysia ser. 2, 6: 70, fig. 1 (2017); Wong, Checkl. P1. Sp. Nee Soon Swamp Forest 8 (2013). - Acer javanicum Jungh., [Tijdschr. Natuurk. Gesch. Physiol. 8: 391 (1841), nom. nud.] Monatsber. Verh. Ges. Erdk. Berlin 3: 96 (1842), non Burm.f. (1768). - TYPE: [Indonesia], West Java, Megamendong, s.d., Junghuhn s.n. (lectotype L [L0014688], designated by Noorsiha (1995: 3); isolectotype BO). (Fig. 1).

Further synonyms are listed by Noorsiha (2004) and van Welzen (2017).

Evergreen tree up to $30 \mathrm{~m}$ tall, buttress up to $2 \mathrm{~m}$ high, bole cylindrical. Bark brown or greyish brown, shallowly fissured or scaly; inner bark reddish brown, fibrous; sapwood white to pale yellow. Twigs slender green to greyish-brown, glabrous; axillary buds prominent when young. Leaves simple, opposite, decussate, sometimes whorled in saplings; petiole 3-6 cm long, slender, glabrous, sometimes slightly whitish, pulvinate at both ends, drying black to brown and usually slightly darker coloured at each end; blade thinly coriaceous, lanceolate or oblong-elliptic to ovate, $9-15 \times 3-8 \mathrm{~cm}$, glossy dark green, glabrous adaxially, glaucous or whitish, glabrous or sometimes pubescent abaxially, apex shortly acuminate to obtuse, base rounded or cuneate to broadly cuneate, margin entire except coarsely and distantly toothed on young seedling, midrib slightly raised above and prominent below, basally tri-veined, these extending to half of blade length or more, secondary veins 5-8 pairs, tertiary veins slender reticulate and visible on both surfaces. Inflorescences cymose-paniculate to corymbose, in axils of fallen leaves, 2.5-10 cm long, glabrous or pubescent; peduncle 5-35 mm long; pedicel 4-17 mm long, glabrous. Staminate flowers with sepals and petals (3-)5, free, obliquely erect, respectively $2.5-3$ and 1.5-2.5 mm long; stamens (4-)6(-8), arranged in one whorl within a flat, glabrous to woolly disc, filaments c. $5 \mathrm{~mm}$ long, anthers c. $1 \mathrm{~mm}$ long; pistillode rudimentary. Pistillate flowers with sepals and petals as in the staminate ones; stamens rudimentary; ovary densely hairy, c. $2 \mathrm{~mm}$ across; styles 2 , c. $1.5 \mathrm{~mm}$ long, stigmas 2, sessile. Fruits with peduncle 1-3 cm long, stout; samaras paired, reddish, strongly veined, wings falcate, spreading acutely, broadest near apex, including nutlet 4-7 × 1-2.5 cm; nutlets slightly convex, c. $15 \times 7 \mathrm{~mm}$, pubescent or nearly glabrous.

Distribution. India, Nepal, southwestern China, Myanmar, Laos, Vietnam, Cambodia, Thailand, Peninsular Malaysia, Singapore, Borneo, Sumatra, Java, Timor, Sulawesi and Philippines. 
Habitat and ecology. In Singapore, Acer laurinum has only been found in the Nee Soon swamp forest (Fig. 1 \& 2). Within the Malesian region, Acer laurinum is mainly found in primary forests and is usually associated with soils of high nutrient content growing on igneous rocks, in hill or montane seasonal forests 900 to $2550 \mathrm{~m}$ (Bloembergen, 1948; Noorsiha, 2004; van Welzen, 2017). Van Welzen (2017) records it as also occurring in peat swamp forest at low altitudes in Johor. It is locally abundant in a few montane areas of Sarawak (Noorsiha, 2004). It is also recorded as suitable for use in restoration planting in tropical montane forests in the Bromo Tengger Semeru National Park of East Java (Hakim \& Miyakawa, 2013; Hariyati et al., 2013; Hidayat \& Suhendri, 2020). Outside of Malesia, it is found in evergreen forests at 700-2500 $\mathrm{m}$ in southern China (Guangxi, Yunan, Hainan and Tibet) and noted to be relatively rare (Xu et al., 2008). The flowering and fruiting phenology of Acer laurinum has not been observed in Singapore but has been recorded as coinciding with higher levels of precipitation in West Java (Hidayat \& Suhendri, 2020) and as flowering in January in Peninsular Malaysia (van Welzen, 2017).

Vernacular names. Putih dadah (West Java), perdu (Sarawak).

Uses. The wood of Acer laurinum is used for simple construction and furniture by locals in Tengger highland in Indonesia (Hakim \& Miyakawa, 2013).

Provisional IUCN Conservation assessment. With a single locality for the species in Singapore and only a few individuals recorded, we assess this species here as nationally Critically Endangered (CR/D) (IUCN Standards and Petitions Subcommittee, 2017), agreeing with the assessment given by Wong et al. (2013).

Specimens examined. SINGAPORE: Central Catchment Nature Reserve: Nee Soon Swamp Forest, 3 Mar 2010, Gwee SING2010-475 (SING [SING0144684]); Nee Soon Freshwater Swamp Forest, 4 Feb 2020, Lam et al. SING2020-659 (SING [SING0294231]).

INDONESIA: Java: West Java, Megamendong, Junghuhn s.n. (L [L0014688]); Junghun s.n. (K [K000640924], U [U0000140]); collector unknown s.n., 1903 (US [US01242230]).

PHILIPPINES: Luzon: Mt Data, Nov 1905, Merrill 4528 (K [K000640922]); Luzon Central, Loher 4518 (K [K000640921]).

THAILAND: Chiang Mai: Doi Kar (Inthanon), 21 Oct 1910, Garrett 77 (K [K000640927]). CHINA: Hainan: Hung Mo Shan, 6 Jun 1929, Tsang \& Fung 253 (K [K000640909]).

\section{Discussion}

Acer laurinum is mainly found in subtropical evergreen forests (Xu et al., 2008) and tropical montane forests (Bloembergen, 1948; Noorsiha, 2004), but records of this species from lowland habitats of the tropics are rare, with only one record from a lowland habitat in Basilan, Philippines and records of collections from peat swamp forests of southern Peninsular Malaysia (LaFrankie, 2010; van Welzen, 2017). In Singapore's NSSF this species additionally occurs in freshwater swamp forest 


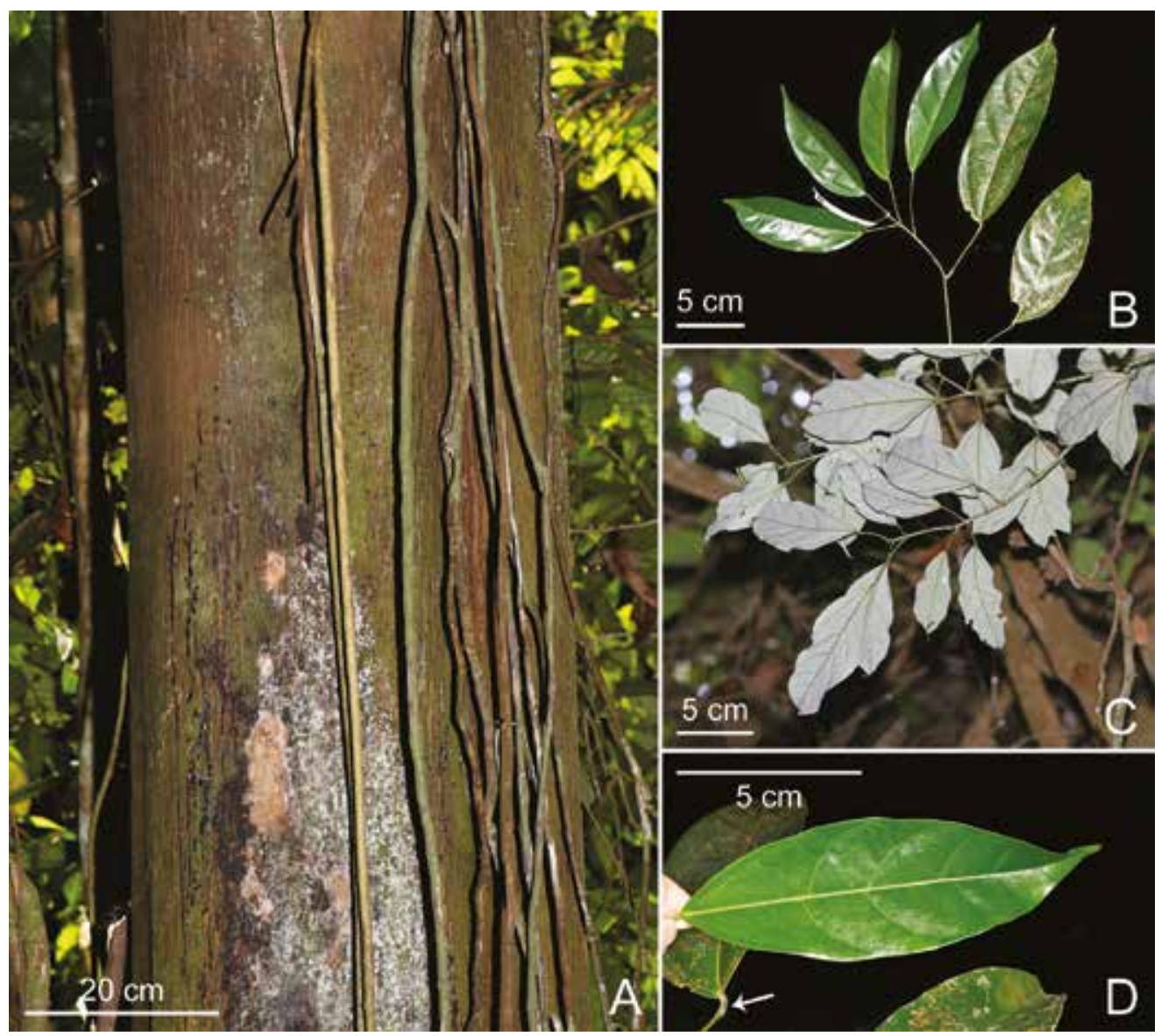

Fig. 1. Acer laurium Hassk. A. Bark of mature tree in situ. B. Oppositely arranged leaves of Acer laurinum collected from sapling encountered. C. Abaxial surfaces of the oppositely arranged leaves. D. Adaxial surface of lamina with upper pulvinus indicated by white arrow. All from Nee Soon Swamp Forest. (Photos: A \& C, W.N. Lam; B \& D, Y.Y. Ting).

suggesting that it has a wider niche breadth than previously recognised. The mature individual (48.3 cm diameter at breast height) that we encountered was found deep within the swamp area of the Nee Soon catchment (Fig. 2), growing alongside other freshwater swamp specialists such as Madhuca sp., Mastixia trichotoma Blume, Pometia pinnata J.R.Forst \& G.Forst and Palaquium xanthochymum (de Vriese) Pierre ex Burck. Although generalist tree species are often able to persist in waterlogged soils and often occur as saplings in swamp habitats, within the NSSF, large trees with diameters exceeding $30 \mathrm{~cm}$ almost always belong to specialist swamp species. Additionally, the observation of a sapling in a similar habitat not far from the mature individual suggests the existence of a reproductive population of this species in NSSF. Because of this, we argue that as Acer laurinum is associated with freshwater swamp habitats in Singapore it is likely to be so more widely in the region as well. 


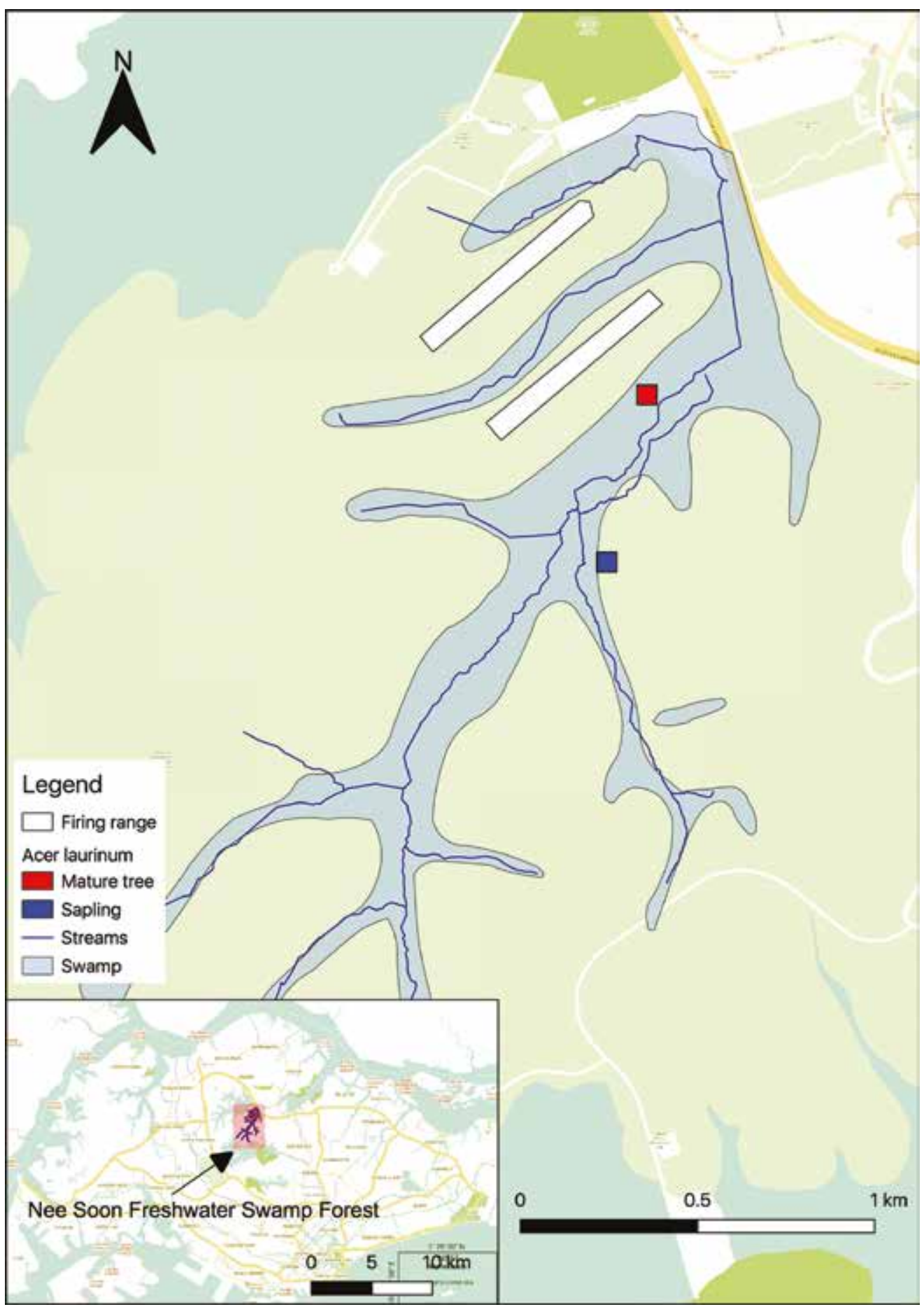

Fig. 2. Map of the Nee Soon Swamp Forest (see O’Dempsey \& Chew, 2013) and approximate location of the two Acer laurinum individuals encountered. 
The discovery of Acer laurinum (Wong et al., 2013) is one of many interesting findings from recent work in the NSSF. However, most recent discoveries/rediscoveries have been of epiphytes, herbs and climbers, while discoveries of tree species have been rare. Acer laurinum demonstrates that there is still much to explore in the NSSF and that there is a need for continued conservation of this last track of pristine freshwater swamp forest in Singapore.

ACKNOWLEDGEMENTS. We would like to thank the National Parks Board for funding our research - Ecological Modelling of Plant Responses to Hydrological Changes in the Nee Soon Swamp Forest under the permit number NP/RP18-002-2b. We also express our appreciation to the Ministry of Defence (MINDEF) for granting access into areas around the firing ranges. We thank Dr David Middleton for his assistance with the nomenclature and typification of Acer laurinum. Finally, we extend our gratitude to Dr Cai Yixiong, Robin Ngiam, Sebastian Ow, Li Tianjiao, Jayasri Lakshminarayanan and Lim Ting Wei for facilitating access into Nee Soon Swamp Forest; and Siti Nur Bazilah for access to SING.

\section{References}

APG (2003). An update of the Angiosperm Phylogeny Group classification for the orders and families of flowering plants: APG II. Bot. J. Linn. Soc. 141(4): 399-436.

Bloembergen, S. (1948). Aceraceae. In: van Steenis, C.G.G.J. (ed.) Flora Malesiana, ser. 1, Seed Plants, vol. 4, pt. 1, pp. 3-4, 592, fig. 1, 2. Djakarta: Noordhoff-Kolff N.V.

Chong, K.Y., Lim, R.C.J., Loh, J.W., Neo, L., Seah, W.W., Tan, S.Y. \& Tan, H.T.W. (2018). Rediscoveries, new records, and the floristic value of the Nee Soon freshwater swamp forest, Singapore. Gard. Bull. Singapore 70(Suppl. 1): 49-69.

Delendick, T.J. (1980). The correct name for the Acer of Malesia. Reinwardtia 9(4): 395-397.

Hakim, L. \& Miyakawa, H. (2013). Plant trees species for restoration program in Ranupani, Bromo Tengger Semeru National Park Indonesia. Biodivers. J. 4(3): 387-394.

Hariyati, J.R., Arisoesilaningsih, E. \& Hakim, L. (2013). Seedling growth of some native trees in Ranu Pani-Ranu Regulo restoration area, Bromo Tengger Semeru National Park. $J$. Biodivers Env. Sci 3(6): 47-55.

Harrington, M.G., Edwards, K.J., Johnson, S.A., Chase, M.W. \& Gadek, P.A. (2005). Phylogenetic inference in Sapindaceae sensu lato using plastid matK and $r b c L$ DNA sequences. Syst. Biol. 30(2): 366-382.

Harris, A., Chen, Y., Olsen, R.T., Lutz, S. \& Wen, J. (2017). On merging Acer sections Rubra and Hyptiocarpa: Molecular and morphological evidence. PhytoKeys 86: 9-42.

Hidayat, I.W. \& Suhendri, Y. (2020). Flowering and fruiting phenology of Acer laurinum (Sapindaceae) at ex-situ conservation site. Prosiding Seminar Nasional Masyarakat Biodiversitas Indonesia 6(1): 500-504.

IUCN Standards and Petitions Subcommittee (2017). Guidelines for using the IUCN Red List Categories and Criteria. Version 13. Prepared by the Standards and Petitions Subcommittee.

LaFrankie J.V. (2010). Trees of Tropical Asia: An Illustrated Guide to Diversity. Manila: Black Tree Publications, Inc. 
Noorsiha, A. (2004). Aceraceae. In: Soepadmo, E., Saw, L.G. \& Chung, R.C.K. (eds) Tree Flora of Sabah and Sarawak, vol. 1, pp. 1-4. Kuala Lumpur: Forest Research Institute Malaysia.

O'Dempsey, T. \& Chew, P.T. (2013). The Freshwater Swamp Forests of Sungei Seletar Catchment: A Status Report. In: Leong, T.M. \& Ho, H.C. (eds) Proceedings of the Nature Society, Singapore's Conference on Nature Conservation for a Sustainable Singapore, pp. 121-166. Singapore: The Nature Society (Singapore).

Radlkofer, L. (1890). Ueber die Gliederung der Familie der Sapindaceen. Sitzungsber. Königl. Bayer. Akad. Wiss. München 20: 105-379.

Radlkofer, L. (1933). Sapindaceae. In: Engler, A. (ed.) Das Pflanzenreich: Regni Vegetabilis Conspectus, IV, 165 (Heft 98ah). Leipzig: Verlag von Wilhelm Engelmann.

Van Welzen, P.C. (2017). Sapindaceae. In: Kiew, R., Chung, R.C.K., Saw, L.G. \& Soepadmo, E. (eds) Flora of Peninsular Malaysia, ser. 2, vol. 6, pp. 63-191. Kepong: Forest Research Institute Malaysia.

Whitmore, T.C. (1973). Aceraceae. In: Whitmore, T.C. (ed.) Tree Flora of Malaya, vol. 2, pp. 1-2. Kuala Lumpur: Longman Malaysia.

Wong, H.F., Tan, S.Y., Koh, C.Y., Siow, H.J.M., Li, T., Heyzer, A., Ang, A.H.F., Mirza Rifqibin Ismail, Srivathsan, A. \& Tan, H.T.W. (2013). Checklist of the Plant Species of Nee Soon Swamp Forest, Singapore: Bryophytes to Angiosperms. Singapore: National Parks Board and Raffles Museum of Biodiversity Research, National University of Singapore. Xu, T., Chen, Y., de Jong, Piet. C., Oterdoom, H.J. \& Chang, C. (2008). Aceraceae. In: Wu, Z.Y., Raven, P.H., Hong, D.Y. (eds) Flora of China, vol. 11, pp. 515-553. Beijing: Science Press; and St. Louis: Missouri Botanical Garden Press. 